\title{
Management of the difficult airway in children
}

G. Johnson MD FRCP

(Summary not available) 